\title{
Second annual UK Purine Club Symposium report 2010
}

\author{
Stephen P. H. Alexander • Vera Ralevic
}

Published online: 22 December 2010

(C) Springer Science+Business Media B.V. 2010

The second annual UK Purine Club Symposium was held on September 17, 2010 at the Jubilee Campus, University of Nottingham. The award-winning Jubilee campus is a relatively recent (opened in 1999) addition to the University of Nottingham and boasts some unique and highly distinctive architecture, which we were able to enjoy. We were fortunate that the day was sunny, so breaks could be taken outside, by the lakeside. For most delegates, Nottingham proved to be relatively convenient to get to, situated as it is in the Midlands (and home of Sherwood Forest and Nottingham Forest Football Club).

The meeting was attended by over 80 delegates from all over the UK. The meeting got off to a great start with an invited lecture from Professor Geoffrey Burnstock, who described the difficulties in trying to establish purinergic signalling among the scientific community, and then brought us up to date with some recent developments in the field. The high standard was maintained by the other guest speakers: Ad Izerman gave a fascinating account of the allosteric modulation of adenosine receptors; Richard Evans enthralled us with an account of $\mathrm{P} 2 \mathrm{X}_{1}$ receptor trafficking and Stephen Hill described how fluorescent ligands can be used to study adenosine receptor allosterism and dimerisation in living cells. There were a number of excellent and diverse oral and poster communications presented over the day. The day was a nice opportunity to meet colleagues in the purine field and, especially for some of our younger members, to put faces to names. Lively scientific discussion took place during the poster sessions, and even livelier discussion at the wine reception. Twenty-six of us went to the symposium dinner at the Hemsley, Nottingham University's equivalent of Ramsey's, where there was further scientific discussion (although it is unclear how much of this was remembered the following day).

Costs were kept low, particularly for postgraduate students, thanks to the support of Ascent Scientific, Bioline, New England Biolabs, Sarissa Biomedical and Tocris Bioscience.

We really enjoyed hosting the Purine Club meeting at Nottingham and look forward to seeing you at the next meeting in 2011.

Vera Ralevic and Steve Alexander

S. P. H. Alexander $\cdot$ V. Ralevic $(\bowtie)$

School of Biomedical Sciences,

University of Nottingham Medical School,

Nottingham NG7 2UH, UK

e-mail: Vera.Ralevic@nottingham.ac.uk 